\title{
Effects of Helichrysum bracteatum flower extracts on UVB irradiation-induced inflammatory biomarker expression
}

\author{
Yun Jeong Kim¹, Ji Hyun Seok', Waiting Cheung ${ }^{2}$, Sung-Nae Lee ${ }^{3}$, Hyun Hee Jang ${ }^{4}$, Seunghee Ba ${ }^{5^{*}}$ (D) and
} Hyunsang Lee 1,5* $^{*}$

\begin{abstract}
Background: The present study aimed to investigate the anti-inflammatory activity of Helichrysum bracteatum $(\mathrm{H}$. bracteatum) flower extracts in vitro.

Methods: $H$. bracteatum flowers were extracted with water, ethanol and 1,3-butylene glycol, and the anti-oxidative activities of the extracts were measured using a 2,2-diphenyl-1-picrylhydrazyl (DPPH) assay. The inhibition of the expression of inflammation-related genes, including tumour necrosis factor-alpha (TNF-a), interleukin-6 (IL-6) and cyclooxygenase-2 (COX-2), was evaluated in vitro using reverse transcription-PCR in ultraviolet B (UVB)-irradiated human epidermal keratinocytes (HEKa cells). To investigate the inhibitory effects of $\mathrm{H}$. bracteatum flower extracts on UVB-induced inflammatory responses in HEKa cells, the production of nitric oxide (NO) and TNF-a was measured using enzyme-linked immunosorbent assays. Results were expressed as the mean \pm standard deviation; statistical significance was calculated using the Student's t-test.
\end{abstract}

Results: The DPPH assay results showed that $H$. bracteatum flower extracts have good anti-oxidative effects and inhibited the expression of inflammation-related genes IL-6, COX-2 and TNF-a. Moreover, the production of NO and TNF-a was inhibited by $\mathrm{H}$. bracteatum flower extracts.

Conclusions: These findings indicate that $\mathrm{H}$. bracteatum flower extracts have efficacy against UVB-induced inflammation-related gene expression.

Keywords: Anti-inflammation, Helichrysum bracteatum flowers, TNF-a, COX-2, IL-6

\section{Background}

Skin serves as a barrier between the human body and environmental stresses, such as pollution, ultraviolet (UV) radiation and other factors. These stresses trigger inflammatory and immune responses in the skin by stimulating the biosynthesis and release of proinflammatory cytokines, such as tumour necrosis factor (TNF) and interleukins (ILs) (Kwon et al. 2001; Parrado et al. 2019; Takashima and Bergstresser 1996; Pupe et al. 2002; Nedoszytko et al. 2014; Striz et al. 2014). It has been reported that chronic inflammation leads to the

\footnotetext{
* Correspondence: sbae@konkuk.ac.kr; andrei.lee@mannay.com

${ }^{5}$ Department of Cosmetics Engineering, Graduate School of Konkuk University, Seoul 05029, Republic of Korea

'Mannay Asia R\&D Center, Anyang-siGyunggi-do, 14059, Republic of Korea Full list of author information is available at the end of the article
}

development and progression of skin diseases (Benedetto et al., 2012; Masuoka et al. 2012; Lee and Chang 2012). For example, cyclooxygenase-2 (COX-2) and inducible nitric oxide (NO) synthase, which are enzymes produced during inflammatory responses induced by UV damage, produce prostaglandin E2 and NO, respectively (Giuliano and Warner 2002; Schafer and Werner 2008; Hong et al. 2002; Jean et al. 2008). Meanwhile, prolonged UV exposure promotes photoageing, which is primarily mediated by reactive oxygen species (ROS) that deplete anti-oxidant defence systems in the skin. At a histological level, photoaged skin is characterized by a loss of collagen and elastin fibres (Rhie et al. 2001).

As a result of environmental stress-mediated ROS synthesis, a wide array of signalling pathways can be aberrantly activated, leading to the abnormal expression of

(C) The Author(s). 2019 Open Access This article is distributed under the terms of the Creative Commons Attribution 4.0 International License (http://creativecommons.org/licenses/by/4.0/), which permits unrestricted use, distribution, and 
inflammatory genes (Varga et al. 2013). Upon their activation, macrophages express an increased level of $\mathrm{NO}$ (Kim et al. 2001; Nathan and Hibbs Jr 1991).

Increasing levels of pollution introduce considerable amounts of hazardous chemicals into the environment, which subsequently cause skin irritation and inflammation from prolonged exposure. Therefore, corticosteroids have been widely used for the treatment of inflammatory skin diseases to effectively ameliorate inflammation. However, prolonged treatment with corticosteroid preparations may lead to side effects, such as skin atrophy and cutaneous reactivity (Hughes et al. 1995). Thus, the development and use of more effective antiinflammatory agents are desired.

In the field of herbal medicine, extensive evidence has shown that plants synthesize anti-oxidants and antiinflammatory compounds to suppress UV radiationmediated ROS. Helichrysum bracteatum (H. bracteatum) is an annual herb that has been naturalized at high altitudes. $H$. bracteatum was originally found in Australia and is now widely grown in China (Liu et al. 2007). Helichrysum spp. are rich in secondary metabolites that have medicinal value (Kelmanson et al. 2000). However, the anti-inflammatory activity of $H$. bracteatum flower extracts has not been widely studied. Therefore, the present study was undertaken to investigate the antioxidative and anti-inflammatory effects of $H$. bracteatum flower extracts in vitro on the expression of inflammatory biomarkers (TNF- $\alpha$, IL- 6 and COX-2).

\section{Methods}

\section{Preparation of $\mathrm{H}$. bracteatum flower extracts}

Dried $H$. bracteatum flowers were ground and extracted in 20 volumes of extraction solvent at room temperature for $24 \mathrm{~h}$ with vigorous shaking. For extraction purposes, water, 50\% ethanol, 95\% ethanol, 50\% 1,3-butylene glycol and 100\% 1,3-butylene glycol were used. The mixtures were then filtered using filter paper (No. 2 qualitative filter papers, Whatman, England), and the resulting filtrates were concentrated under vacuum using a rotary evaporator (N-1110, EYELA, USA). The concentrated extracts were stored at $-20{ }^{\circ} \mathrm{C}$ until further use.

\section{Cell line}

Human epidermal keratinocytes (HEKa cells) were cultured in Dulbecco's modified Eagle's medium (Gibco, Thermo Fisher Scientific, USA) containing 1\% of penicillin/streptomycin (Sigma Aldrich, USA) and 10\% of foetal bovine serum (Gibco, USA) at $37{ }^{\circ} \mathrm{C}$ in a $5 \% \mathrm{CO}_{2}$ incubator.

\section{Cytotoxicity}

Cytotoxicity was determined using the modified Mosmann's method (Mosmann 1983). Approximately $1 \times$
$10^{5}$ HEKa cells were seeded into a 96-well plate and incubated for $24 \mathrm{~h}$. After $24 \mathrm{~h}$, the cells were then treated with $H$. bracteatum flower extracts at the following concentrations: $10,20,50,100$ and $500 \mu \mathrm{g} / \mathrm{mL}$. After treatment for $24 \mathrm{~h}$, the cells were washed twice with phosphate-buffered saline, and $0.5 \mathrm{mg} / \mathrm{mL} 3$-(4,5-dimethylthiazol-2-yl)-2,5-diphenyltetrazolium bromide (MTT) was subsequently added to each well. After incubation for $4 \mathrm{~h}$ with MTT, $150 \mu \mathrm{L}$ dimethyl sulfoxide was added to each well and mixed thoroughly to dissolve the dark blue crystals. After $20 \mathrm{~min}$, when all the crystals were dissolved at room temperature, the absorbance at $570 \mathrm{~nm}$ was measured using spectrophotometry.

\section{DPPH free radical-scavenging activity assay}

The free radical-scavenging activity of $H$. bracteatum flower extracts and the effects of the extraction solvents on this activity were determined using the 2,2-diphenyl-1-picrylhydrazyl (DPPH) assay. Briefly, $50 \mu \mathrm{L}$ of the diluted $H$. bracteatum flower extracts were mixed with $100 \mu \mathrm{L}$ of $0.1 \mathrm{mM}$ DPPH solution. DPPH solution without the test sample was used as a control. Next, the absorbance was measured at $515 \mathrm{~nm}$ after the mixture was incubated for $30 \mathrm{~min}$ at room temperature. The antioxidative activity was calculated using the formula below and expressed as the percentage of DPPH radical elimination:

$$
\left[\frac{\mathrm{A}_{\text {blank }}-\mathrm{A}_{\text {sample }}}{\mathrm{A}_{\text {blank }}}\right] \times 100(\%),
$$

where $A_{\text {blank }}$ is the absorbance of the blank DPPH solution and $\mathrm{A}_{\text {sample }}$ is the absorbance of the DPPH solution after the addition of $H$. bracteatum flower extracts.

\section{TNF-a concentration}

Approximately $1 \times 10^{5}$ HEKa cells were seeded into a 96-well plate and cultured for $18 \mathrm{~h}$. Next, the cells were treated with $100 \mu \mathrm{g} / \mathrm{mL} H$. bracteatum flower extracts. After $24 \mathrm{~h}$ of culture, the cells were irradiated with 200 $\mathrm{mJ} / \mathrm{cm}^{2}$ UVB for $10 \mathrm{~min}$, and the supernatant was harvested to determine the TNF- $\alpha$ concentration. The human TNF- $\alpha$ ELISA kit (Abcam, England) was used, according to the manufacturer's instructions. Absorbance was measured at $450 \mathrm{~nm}$ using a microplate reader (Epoch2C, BioTek, USA).

\section{NO concentration}

A NO detection kit (Intron biotechnology, Korea) was used to determine the $\mathrm{NO}$ concentration. Approximately $1 \times 10^{5}$ HEKa cells were seeded into a 96-well plate and cultured for $18 \mathrm{~h}$. Next, the cells were treated with different concentrations of the $H$. bracteatum flower extracts. After $24 \mathrm{~h}$ of treatment, the cells were irradiated 
with $200 \mathrm{~mJ} / \mathrm{cm}^{2}$ UVB for $10 \mathrm{~min}$, and the supernatants were used to determine the NO concentrations, according to the manufacturer's instructions. Absorbance at $540 \mathrm{~nm}$ was measured using a microplate reader (Epoch2C, BioTek). Sodium nitrate was used to obtain a standard curve, and the obtained absorbance values were used to calculate the NO concentration in the cell cultures.

\section{RNA isolation and reverse transcription (RT)-PCR}

The total RNA of treated and untreated cells was isolated using the RNAiso reagent (Takara, Japan), according to the manufacturer's instructions. Following the validation of purified RNA using spectrophotometry, the RNA was converted into cDNA using the First-Strand cDNA Synthesis SuperMix kit (Tragen, China). The converted cDNA was used as a template for amplification using PCR primers (Bioneer, Korea). The specific forward and reverse primers for each gene are presented in Table 1. Subsequently, the PCR products were loaded on a 1\% agarose gel and evaluated using the Gel Documentation system (GelDoc EZ system, BioRad, Korea).

\section{Statistical analysis}

All experiments were conducted in triplicate; data are shown as the mean \pm standard deviation. Statistical analysis was performed with Microsoft Excel (Microsoft, USA) using the Student's $t$-test.

\section{Results}

Anti-oxidative effects of $H$. bracteatum flower extracts

The effects of $H$. bracteatum flower extracts on free radical scavenging were confirmed using a DPPH assay. The results showed that the anti-oxidative effects of $H$. bracteatum flower extracts increased in a concentrationdependent manner. Among the five different solvents examined, a $50 \%$ ethanolic extract of $\mathrm{H}$. bracteatum flowers exhibited the highest free radical-scavenging effects $(84 \%)$, which was higher than that of quercetin (the positive control) (Fig. 1).

\section{Cell viability after treatment with $H$. bracteatum flower extracts}

The viability of HEKa cells was measured after treatment for $24 \mathrm{~h}$ with $H$. bracteatum flower extracts at concentrations of $10,20,50,100$ and $500 \mu \mathrm{g} / \mathrm{mL}$. The results

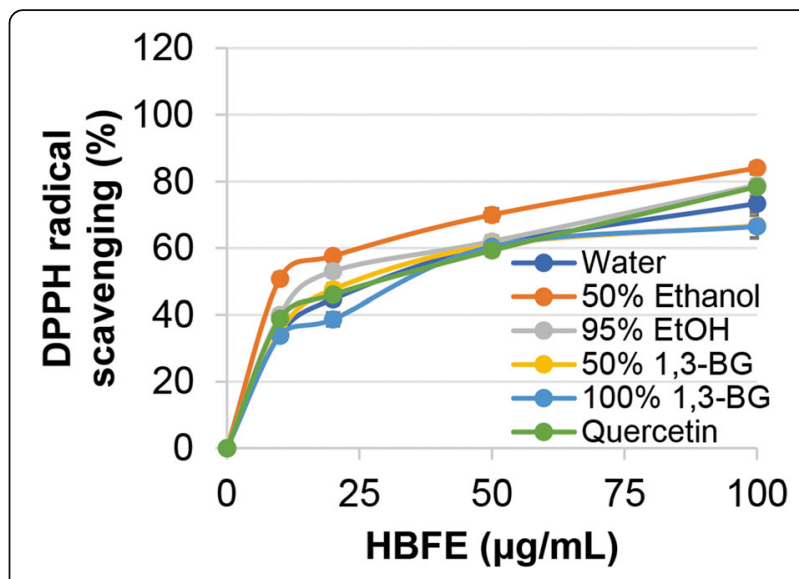

Fig. 1 DPPH free radical-scavenging activity of $H$. bracteatum flower extracts (HBFE)DPPH free radical-scavenging activity of $\mathrm{H}$. bracteatum flower extracts (HBFE) prepared using five different solvents (water, $50 \%$ ethanol, 95\% ethanol, 50\% 1,3-butylene glycol and 100\% 1,3butylene glycol) was examined. Quercetin was used as a positive control. The results are expressed as the mean \pm SD of three independent experiments.

showed that cell viability decreased when higher concentrations of the extract were added: $91.14 \%$ with $10 \mu \mathrm{g} / \mathrm{mL}$ extract, $88.61 \%$ with $20 \mu \mathrm{g} / \mathrm{mL}$ extract, $83.12 \%$ with $50 \mu \mathrm{g} /$ $\mathrm{mL}$ extract and $82.28 \%$ with $100 \mu \mathrm{g} / \mathrm{mL}$ extract. At 500 $\mu \mathrm{g} / \mathrm{mL}$, the $H$. bracteatum flower extract reduced cell viability to $77.64 \%$; hence, it was considered cytotoxic. Therefore, $100 \mu \mathrm{g} / \mathrm{mL}$ was the maximum concentration that was used for subsequent experiments (Fig. 2).

\section{Inhibition of TNF-a production}

The effects of $H$. bracteatum flower extracts on the inhibition of TNF- $\alpha$ production were assessed using an ELISA kit. The results showed that the expression of the TNF- $\alpha$ gene in HEKa cells was inhibited in a dosedependent manner. TNF- $\alpha$ production levels were measured as $302.35 \mathrm{pg} / \mathrm{mL}$ with $5 \mu \mathrm{g} / \mathrm{mL}$ extracts, 274.65 $\mathrm{pg} / \mathrm{mL}$ with $10 \mu \mathrm{g} / \mathrm{mL}$ extracts, $266.52 \mathrm{pg} / \mathrm{mL}$ with 20 $\mu \mathrm{g} / \mathrm{mL}$ extracts, $266.52 \mathrm{pg} / \mathrm{mL}$ with $50 \mu \mathrm{g} / \mathrm{mL}$ extracts and $188.60 \mathrm{pg} / \mathrm{mL}$ with $100 \mu \mathrm{g} / \mathrm{mL}$ extracts, whereas 10 $\mu \mathrm{M}$ hydrocortisone resulted in the production of 122.77 pg/mL TNF- $\alpha$ (Fig. 3).

\section{Inhibition of NO production}

To determine the effects of $H$. bracteatum flower extracts on NO production in HEKa cells, cells were

Table 1 Primer sequences used for RT-PCR

\begin{tabular}{lll}
\hline Gene & Forward primer $\left(5^{\prime} \rightarrow 3^{\prime}\right)$ & Reverse primer $\left(5^{\prime} \rightarrow 3^{\prime}\right)$ \\
\hline GAPDH & ATTGTTGCCATCAATGACCC & AGTAGAGGCAGGGATGATGT \\
IL-6 & ATGAACTCCTTCTCCACAAGCGC & GAAGAGCCCTCAGGCTGGACTG \\
TNF- $a$ & CATTCTGGGAGGGGTCTTCC & GGTTGAGGGTGTCTGAAGGA \\
COX-2 & TTCAAATGAGATTGTGGGAAAAT & AGATCATCTCTGCCTGAGTATCTT \\
\hline
\end{tabular}




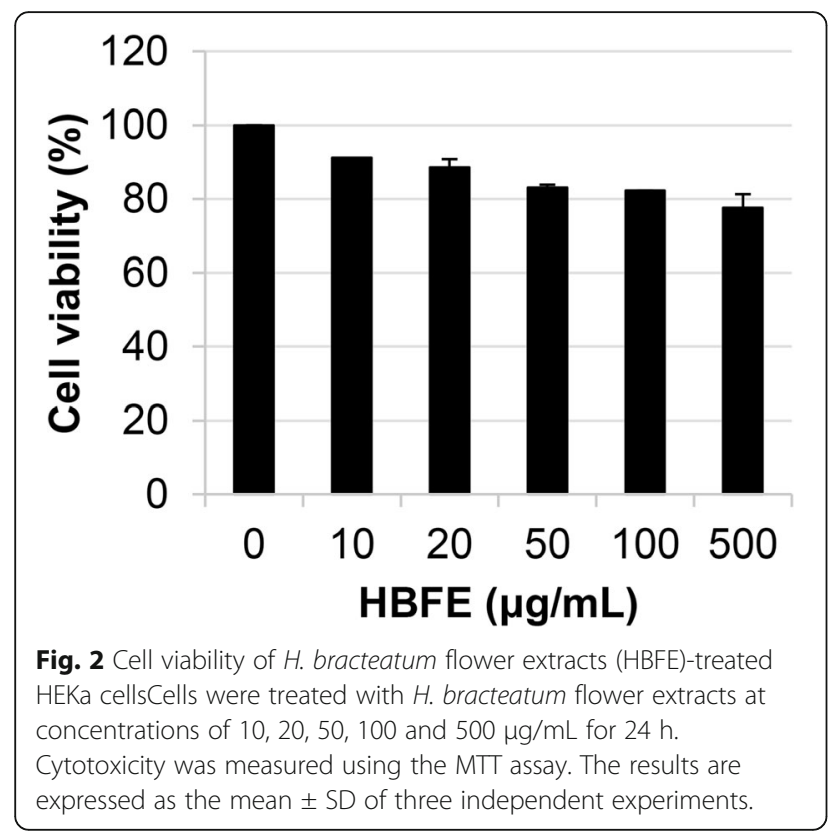

treated with $H$. bracteatum flower extracts at concentrations of $5,10,20,50$ and $100 \mu \mathrm{g} / \mathrm{mL}$. The results showed that the production of NO in HEKa cells was inhibited by $H$. bracteatum flower extracts in a dose-dependent manner. The amounts of NO were measured as 30.97 $\mu \mathrm{M}$ with $5 \mu \mathrm{g} / \mathrm{mL}$ extracts, $30.56 \mu \mathrm{M}$ with $10 \mu \mathrm{g} / \mathrm{mL}$ extracts, $30.28 \mu \mathrm{M}$ with $20 \mu \mathrm{g} / \mathrm{mL}$ extracts, $28.19 \mu \mathrm{M}$ with $50 \mu \mathrm{g} / \mathrm{mL}$ extracts and $24.72 \mu \mathrm{M}$ with $100 \mu \mathrm{g} / \mathrm{mL}$ extracts, whereas $10 \mu \mathrm{M}$ hydrocortisone treatment resulted in the production of $19.72 \mu \mathrm{M}$ NO (Fig. 4).

Gene expression levels of cytokines (IL-6, TNF- $a$ and COX2)

The effects of $H$. bracteatum flower extracts on the inhibition of $I L-6$ gene expression were studied using

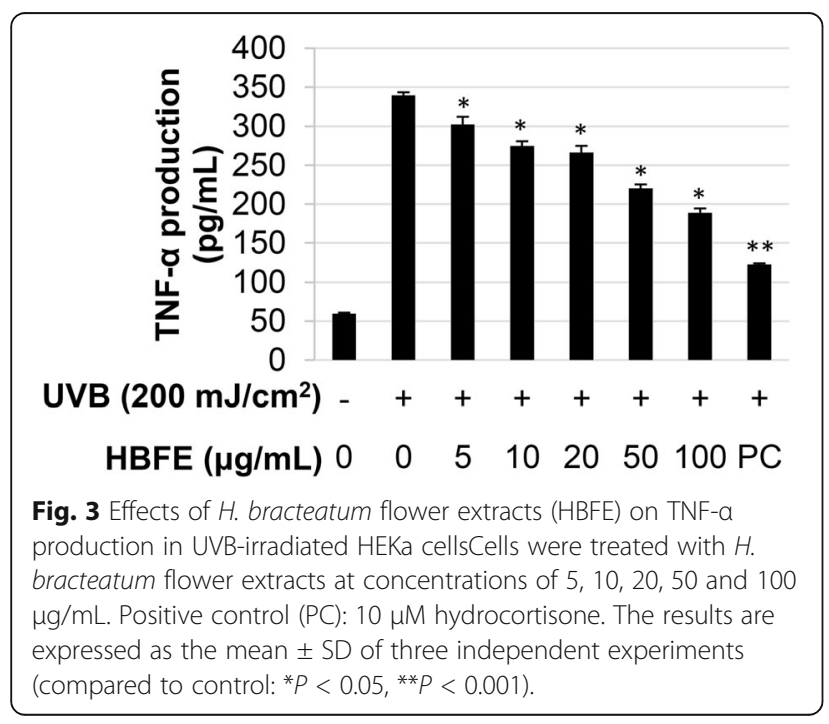

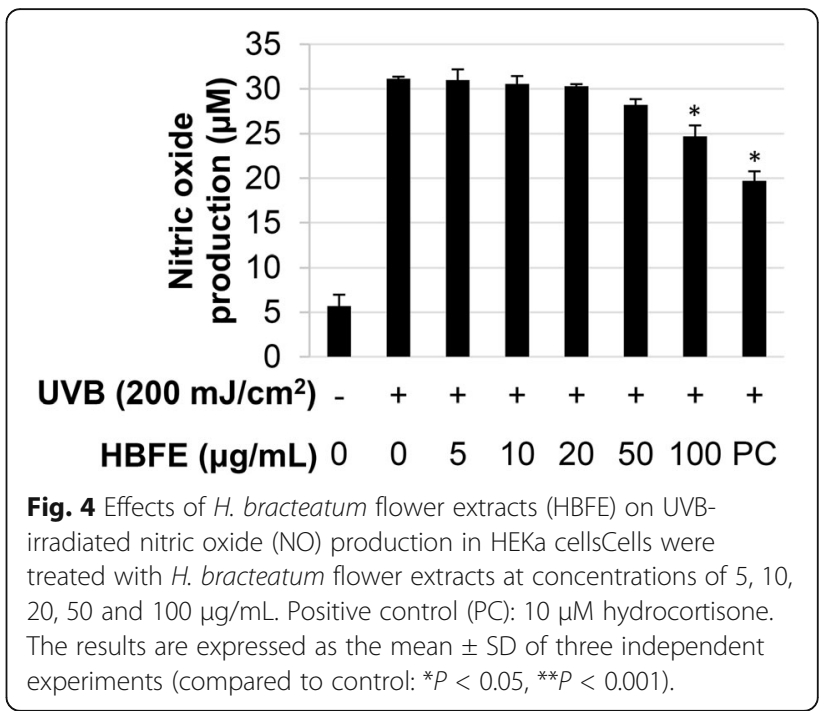

RT-PCR. The results showed that the expression of the IL-6 gene in HEKa cells was inhibited in a dosedependent manner. IL-6 expression levels were measured as $82.73 \%$ with $5 \mu \mathrm{g} / \mathrm{mL}$ extracts, $73.56 \%$ with 10 $\mu \mathrm{g} / \mathrm{mL}$ extracts, $51.42 \%$ with $20 \mu \mathrm{g} / \mathrm{mL}$ extracts, $50.45 \%$ with $50 \mu \mathrm{g} / \mathrm{mL}$ extracts and $41.27 \%$ with $100 \mu \mathrm{g} / \mathrm{mL}$ extracts, whereas $10 \mu \mathrm{M}$ hydrocortisone resulted in an $I L-6$ expression level of $29.34 \%$ (Fig. 5a).

Similarly, $H$. bracteatum flower extracts inhibited the expression of the TNF- $\alpha$ gene in HEKa cells in a dosedependent manner. TNF- $\alpha$ expression levels were measured as $72.21 \%$ with $5 \mu \mathrm{g} / \mathrm{mL}$ extracts, $69.83 \%$ with 10 $\mu \mathrm{g} / \mathrm{mL}$ extracts, $49.93 \%$ with $20 \mu \mathrm{g} / \mathrm{mL}$ extracts, $48.32 \%$ with $50 \mu \mathrm{g} / \mathrm{mL}$ extracts and $40.55 \%$ with $100 \mu \mathrm{g} / \mathrm{mL}$ extracts, whereas $10 \mu \mathrm{M}$ hydrocortisone resulted in a TNF$\alpha$ expression level of $27.05 \%$ (Fig. $5 b$ ).

$H$. bracteatum flower extracts also inhibited the expression of the COX-2 gene in HEKa cells in a dosedependent manner. COX-2 expression levels were measured as $79.78 \%$ with $5 \mu \mathrm{g} / \mathrm{mL}$ extracts, $72.96 \%$ with 10 $\mu \mathrm{g} / \mathrm{mL}$ extracts, $64.72 \%$ with $20 \mu \mathrm{g} / \mathrm{mL}$ extracts, $53.54 \%$ with $50 \mu \mathrm{g} / \mathrm{mL}$ extracts and $50.81 \%$ with $100 \mu \mathrm{g} / \mathrm{mL}$ extracts, whereas $10 \mu \mathrm{M}$ hydrocortisone resulted in a COX-2 expression level of $36.83 \%$ (Fig. 5c).

\section{Discussion}

$H$. bracteatum flower extracts prepared using five different solvents had anti-oxidative effects greater than $50 \%$ as determined by the DPPH assay. Specifically, the 50\% ethanolic extract showed the highest antioxidative effect of all the tested solvents. Liu et al. reported that $H$. bracteatum extracts contain several well-known anti-oxidants, including quercetin, chrysoeriol and isoorientin (Liu et al. 2007; Yuan et al. 2016; Mishra et al. 2003; Zheng et al. 2017). In this study, the anti-oxidative effects of $H$. bracteatum 


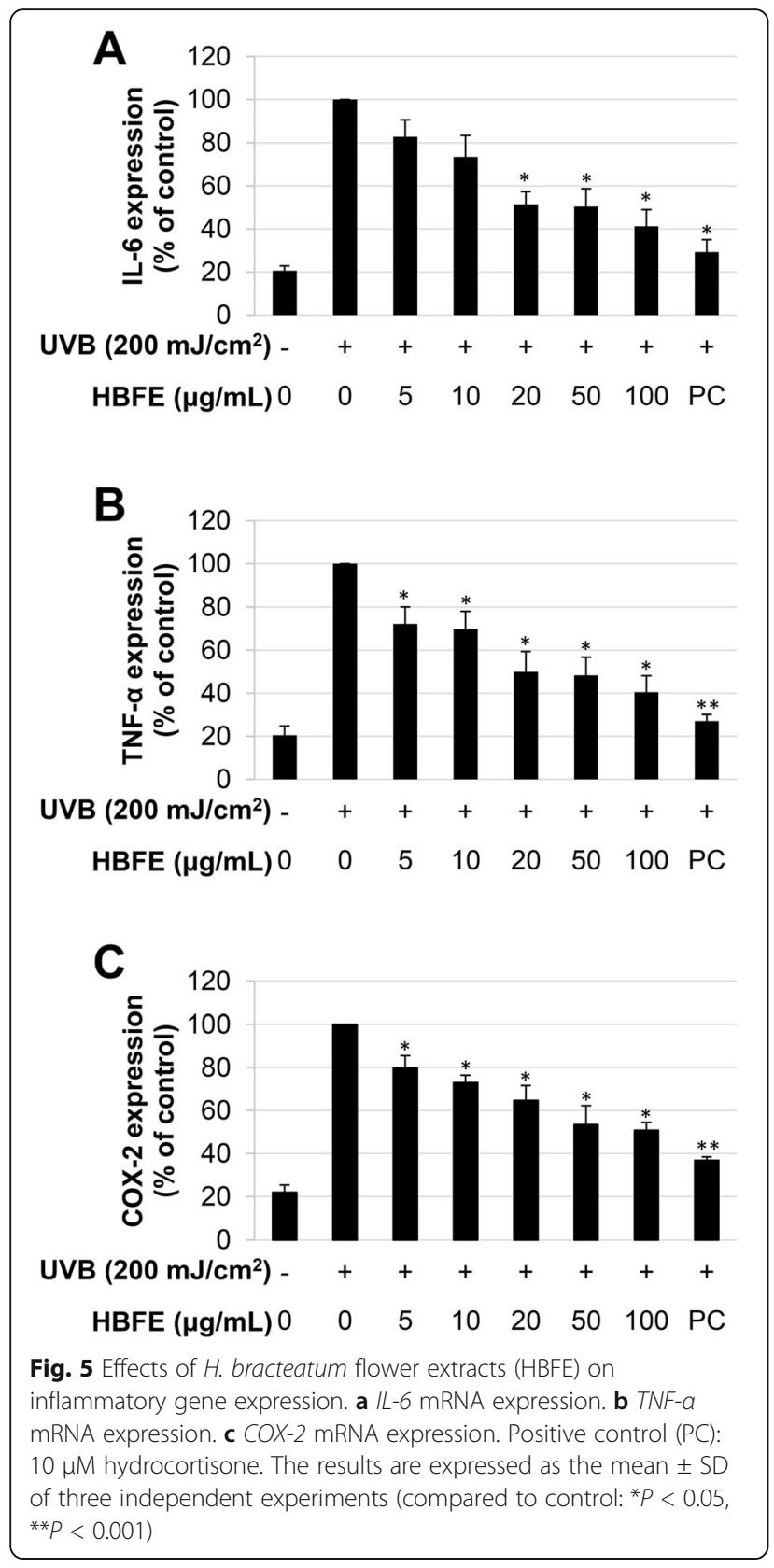

flower extracts prepared with $50 \%$ ethanol were higher than those of quercetin.

Exposure of the skin to environmental or physiological stresses can upregulate TNF- $\alpha$, ILs and other cytokines that cause inflammation. These inflammatory factors retard the growth of skin cells while aggravating skin inflammation and ageing. TNF- $\alpha$ is a prime inducer and driver of inflammatory skin diseases (Han et al. 2001). In this study, the anti-inflammatory effects of $H$. bracteatum flower extracts were studied on human skin cells in vitro. As shown in Fig. 3 , HEKa cells treated with $100 \mu \mathrm{g} / \mathrm{mL} H$. bracteatum flower extracts produced $188.6 \mathrm{pg} / \mathrm{mL}$ TNF- $\alpha$, which is approximately $45 \%$ of levels generated after UVB irradiation. Effects of $H$. bracteatum flower extracts on NO production were also similar. UV irradiation caused the production of 31.11 $\mu \mathrm{M} \mathrm{NO}$, whereas $100 \mu \mathrm{g} / \mathrm{mL}$ H. bracteatum flower extracts caused the production of $24.72 \mu \mathrm{M} \mathrm{NO}$, which was approximately $20 \%$ lower than that of the control. For quercetin, a $37 \%$ reduction of NO production was observed compared to the control (Fig. 4).

HEKa cells irradiated with $200 \mathrm{~mJ} / \mathrm{cm}^{2}$ UVB exhibited increases in the expression levels of TNF- $\alpha$, IL- 6 and COX- 2 . However, $H$. bracteatum flower extracts reduced these expression levels in a dose-dependent manner (Fig. 5).

Liu et al. (2007) reported that prunin (a hypocholesterolaemic agent), quercetin (an inhibitor of tumours and lipid peroxidation), luteolin (an antimicrobial agent), isoorientin (an anti-oxidative, anti-nociceptive and anti-inflammatory agent) and 4-hydroxymethyl-1-methoxycabonylazulene (an anti-inflammatory and antimicrobial agent) were found in ethanolic extracts of $H$. bracteatum flowers. Hence, it is possible that the anti-inflammatory effects of $H$. bracteatum are contributed by isoorientin, 4-hydroxymethyl-1-methoxycabonylaz $\mu$ Lene and quercetin. Thus, chemical analyses and an evaluation of the active compounds in $\mathrm{H}$. bracteatum flower extracts are required.

Overall, our results provide the potential role of $H$. bracteatum flower extracts in the inhibition of UVBinduced inflammatory responses in human keratinocytes. Using various biochemical assays including qRT-PCR and ELISA assays, we show that $H$. bracteatum flower extracts have beneficial functions on keratinocytes. The extracts have the ROS-scavenging effect and also can promote the UV irradiation-induced cellular inflammatory responses, including production of cytokines (TNFa and IL-6), NO and expression of COX-2 gene in human keratinocytes. Since UV irradiation induces acute inflammation in the skin by increasing pro-inflammatory cytokine production in keratinocytes (Lee et al. 2017), our data suggest that $H$. bracteatum flower extracts can potentially be used as the novel dermatological and cosmetic ingredient for reduction of skin inflammation.

\section{Conclusions}

The current findings suggest that a 50\% ethanolic extract of $H$. bracteatum flowers elicits the strongest $\mathrm{DPPH}$ free radical-scavenging activity among the other solvents used for extraction; this extract also ameliorates skin inflammation at the mRNA level, as evidenced by the downregulated expression of IL-6, TNF- $\alpha$ and COX-2 in HEKa cells. In addition, the inhibition of TNF- $\alpha$ and NO production further confirms the anti-inflammatory effects of $H$. bracteatum flower extracts. In conclusion, the findings of this study indicate that $H$. bracteatum flower extracts have efficacy against the expression of inflammation-related genes. 


\section{Abbreviations}

COX: Cyclooxygenase; DMSO: Dimethyl sulfoxide; DPPH: 2,2-Diphenyl-1picrylhydrazyl; ELISA: Enzyme-linked immune sorbent assay; HEKa: Human epidermal keratinocyte; IL: Interleukin; MTT: Methylthiazolyldiphenyltetrazolium bromide; NO: Nitric oxide; PGE: Prostaglandin; ROS: Reactive oxygen species; RT-PCR: Reverse transcription polymerase chain reaction; TNF: Tumour necrosis factor; UV: Ultraviolet

\section{Acknowledgements}

This study was supported by Mannay Asia R\&D Center (Anyang, Korea) and a part of the project (Grant No. 20190070), funded by the Ministry of Oceans and Fisheries, Republic of Korea.

\section{Authors' contributions}

YJK, SB and HL designed the study and drafted the manuscript. YJK and JHS carried out the biochemical assays and revised the manuscript. WC and SNL performed the statistical analysis and helped to revise the manuscript. $\mathrm{HHJ}$, $\mathrm{SB}$ and $\mathrm{HL}$ participated in its design and coordination and helped to draft the manuscript. All authors read and approved the final manuscript.

\section{Funding}

Not applicable.

\section{Availability of data and materials}

Not applicable.

\section{Ethics approval and consent to participate}

Not applicable.

\section{Consent for publication}

Not applicable.

\section{Competing interests}

The authors declare that they have no competing interests.

\section{Author details}

'Mannay Asia R\&D Center, Anyang-siGyunggi-do, 14059, Republic of Korea. ${ }^{2}$ Shenzhen Mannay Cosmetics Co., Ltd, Shenzhen 518000, People's Republic of China. ${ }^{3}$ Department of Cosmetology, Kyung-In Women University, Incheon 21041, Republic of Korea. ${ }^{4}$ School of Cosmetology, Kyungbok University, Namyangju-si, Gyeonggi-do 12051, Republic of Korea. ${ }^{5}$ Department of Cosmetics Engineering, Graduate School of Konkuk University, Seoul 05029, Republic of Korea.

Received: 12 August 2019 Accepted: 14 November 2019

Published online: 11 December 2019

\section{References}

Cerella C, Coppola S, Maresca V, De Nicola M, Radogna F, Ghibelli L. Multiple mechanisms for hydrogen peroxide-induced apoptosis. Ann N Y Acad Sci. 2009;1171:559-63.

De Benedetto A, Kubo A, Beck LA. Skin barrier disruption: a requirement for allergen sensitization. J Invest Dermatol. 2012;132:949-63.

Giuliano F, Warner TD. Origins of prostaglandin E2: involvements of cyclooxygenase (COX)-1 and COX-2 in human and rat systems. J Pharmacol Exp Ther. 2002;303:1001-6.

Han YP, Tuan TL, Wu H, Hughes M, Garner WL. TNF-alpha stimulates activation of pro-MMP2 in human skin through NF-(kappa)B mediated induction of MT1MMP. J Cell Sci. 2001;114:131-9.

Hong CH, Hur SK, Oh OJ, Kim SS, Nam KA, Lee SK. Evaluation of natural products on inhibition of inducible cyclooxygenase (COX-2) and nitric oxide synthase (iNOS) in cultured mouse macrophage cells. J Ethnopharmacol. 2002;83:153-9.

Hughes TK, Fulep E, Juelich T, Smith EM, Stanton GJ. Modulation of immune responses by anabolic androgenic steroids. Int J Immunopharmacol. 1995:17:857-63.

Jean YH, Chen WF, Duh CY, Huang SY, Hsu CH, Lin CS, Sung CS, Chen IM, Wen $\mathrm{ZH}$. Inducible nitric oxide synthase and cyclooxygenase-2 participate in anti-inflammatory and analgesic effects of the natural marine compound lemnalol from Formosan soft coral Lemnalia cervicorni. Eur J Pharmacol. 2008;578:323-31
Kelmanson JE, Jäger AK, van Staden J. Zulu medicinal plants with antibacterial activity. J Ethnopharmacol. 2000;69:241-6.

Kim EJ, Jin HK, Kim YK, Lee HY, Lee SY, Lee KR, Zee OP, Han JW, Lee HW. Suppression by a sesquiterpene lactone from Carpesium divaricatum of inducible nitric oxide synthase by inhibiting nuclear factor-kB activation. Biochem Pharmacol. 2001:61:903-10.

Kwon DJ, Bae YS, Ju SM, Goh AR, Choi SY, Park J. Casuarinin suppresses TNF-ainduced ICAM-1 expression via blockade of NF-KB activation in $\mathrm{HaCaT}$ cells. Biochem Biophys Res Commun. 2001;409:780-5.

Lang JY, Ma K, Guo JX, Sun H. Oxidative stress induces B lymphocyte DNA damage and apoptosis by upregulating p66shc. Eur Rev Med Pharmacol Sci. 2018;22:1051-60

Lee HJ, Chang YC. Suppression of TNF-a-induced inflammation by extract from different parts of Moringa in HaCaT cells. J Life Science. 2012;22:1254-60.

Lee SJ, Lee KB, Son YH, Shin J, Lee JH, Kim HJ, Hong AY, Bae HW, Kwon MA, Lee WJ, Kim JH, Lee DH, Jeong EM, Kim IG. Transglutaminase 2 mediates UVinduced skin inflammation by enhancing inflammatory cytokine production. Cell Death Dis. 2017;8:e3148.

Liu HY, He HP, Yang XW, Chen MW, Hao XJ. Chemical constituents of the flowers of Helichrysum bracteatum. Nat Prod Res Dev. 2007;19:423-6.

Maas-Szabowski N, Shimotoyodome A, Fusenig NE. Keratinocyte growth regulation in fibroblast cocultures via a double paracrine mechanism. J Cell Sci. 1999;112:1843-53.

Masuoka M, Shiraishi H, Ohta S, Suzuki S, Arima K, Aoki S, Toda S, Inagaki N, Kurihara Y, Hayashida S, Takeuchi S, Koike K, Ono J, Noshiro H, Furue M, Conway SJ, Narisawa Y, Izuhara K. Periostin promotes chronic allergic inflammation in response to Th2 cytokines. J Clin Invest. 2012;122:2590-600.

Mishra B, Priyadarsini Kl, Kumar MS, Unnikrishnan MK, Mohan H. Effect of Oglycosilation on the antioxidant activity and free radical reactions of a plant flavonoid, chrysoeriol. Bioorg Med Chem. 2003;11:2677-85.

Mosmann T. Rapid Colorimetiric Assay for cellular growth and survival: application to proliferation and cytotoxicity assays. J Immunol Methods. 1983:65:55-63.

Nathan CF. Secretory products of macrophages. J Clin Invest. 1987;79:319-26.

Nathan CF, Hibbs JB Jr. Role of nitric oxide synthesis in macrophage antimicrobial activity. Curr Opin Immunol. 1991;3:65-70.

Nedoszytko B, Sokołowska-Wojdyło M, Ruckemann-Dziurdzińska K, Roszkiewicz J, Nowicki RJ. Chemokines and cytokines network in the pathogenesis of the inflammatory skin diseases: atopic dermatitis, psoriasis and skin mastocytosis. Postepy Dermatol Alergol. 2014;31:84-91.

Parrado C, Mercado-Saenz S, Perez-Davo A, Gilaberte Y, Gonzalez S, Juarranz A. Environmental stressors on skin aging. Mechanistic Insights. Front Pharmacol. 2019;10:759. https://doi.org/10.3389/fphar.2019.00759.

Pupe A, Moison R, De Haes P, van Henegouwen GB, Rhodes L, Degreef $H$, Garmyn M. Eicosapentaenoic acid, a n-3 polyunsaturated fatty acid differentially modulates TNF-a, IL-1a, IL-6 and PGE2 expression in UVBirradiated human keratinocytes. J Invest Dermatol. 2002;118:692-8.

Rhie G, Shin MH, SEO JY, Choi WW, Cho KH, Kim KH, Park KC, Eun HC, Chung JH. Aging- and photoaging-dependent changes of enzymic and noenzyme antioxidants in the epidermis and dermis of human skin in vivo. J Invest Dermatol. 2001;117:1212-7.

Schafer M, Werner S. Oxidative stress in normal and impaired wound repair. Pharmacol Res. 2008;58:165-71.

Striz I, Brabcova E, Kolesar L, Sekerkova A. Cytokine networking of innate immunity cells: a potential target of therapy. Clin Sci (Lond). 2014;126:593-612.

Takashima A, Bergstresser PR. Impact of UVB radiation on the epidermal cytokine network. Photochem Photobiol. 1996:63:397-400.

Varga A, Budai MM, Milesz S, Bácsi A, Tőzsér J, Benkő S. Ragweed pollen extract intensifies lipopolysaccharide-induced priming of NLRP3 inflammasome in human macrophages. Immunology. 2013;138:392-401.

Yuan L, Wang J, Wu W, Liu Q, Liu X. Effect of isoorientin on intracellular antioxidant defence mechanisms in hepatoma and liver cell lines. Biomed Pharmacother. 2016:81:356-62.

Zheng YZ, Deng G, Liang Q, Chen DF, Guo R, Lai RC. Antioxidant activity of quercetin and its glucosides from propolis: A theoretical study. Sci Rep. 2017;7:7543-53.

\section{Publisher's Note}

Springer Nature remains neutral with regard to jurisdictional claims in published maps and institutional affiliations. 